$1-1-2002$

\title{
The United States of America and the International Criminal Court
}

Diane Marie Amann

University of Georgia School of Law, amann@uga.edu

M.N.S. Sellers

p bepress SSRN

\section{Repository Citation}

Diane Marie Amann and M.N.S. Sellers, The United States of America and the International Criminal Court (2002),

Available at: https://digitalcommons.law.uga.edu/fac_artchop/670

This Article is brought to you for free and open access by the Faculty Scholarship at Digital Commons @ University of Georgia School of Law. It has been accepted for inclusion in Scholarly Works by an authorized administrator of Digital Commons @ University of Georgia School of Law. Please share how you have benefited from this access For more information, please contact tstriepe@uga.edu. 


\section{DIANE MARIE AMANN M.N.S. SELLERS}

\section{The United States of America and the International Criminal Court}

The United States of America has not ratified the treaty establishing a permanent international criminal court, and it is highly unlikely to do so. This is not simply a question of delay caused by cumbersome ratification procedures; rather, it reflects deep-seated opposition by the U.S. executive branch and by many members of Congress. The United States voted against the Rome Statute of the International Criminal Court ${ }^{1}$ when it was adopted on July 17, 1998, at the U.N. Diplomatic Conference of Plenipotentiaries. President William J. Clinton approved signature of the statute on the last day that a state, by signing, could continue to take part in discussions on ICC matters. ${ }^{2}$ But he stressed that he did so largely to remain "in a position to influence the evolution of the court," adding that "I will not, and do not recommend that my successor submit the treaty to the Senate for advice and consent until our fundamental concerns are satisfied."3 Senator Jesse Helms, chairman of the Committee on Foreign Relations, labeled the U.S. signature "as outrageous as it is inexplicable." He promised, "This decision will not stand."4

Diane Marie Amann is Professor of Law, University of California, Davis, School of Law; 2001-02, Professeur invitée, Université de Paris 1 (Panthéon-Sorbonne). B.S., 1979, University of Illinois; M.A., 1981, University of California, Los Angeles; J.D., 1986, Northwestern University. With thanks to Madeline Morris, Leila Nadya Sadat, Ruth Wedgwood, and Tobias Barrington Wolff, who took time to mull issues raised in this report, and to Gwen $K$. Young for research assistance.

M.N.S. SELlers is Professor and Director, Center for International \& Comparative Law, University of Baltimore School of Law, Maryland. Harvard College, A.B., 1980; Oxford University, D.Phil., 1986, B.C.L., 1988; Harvard University, J.D., 1988.

1. U.N. Doc. A/CONF.183/9 (1998), reprinted in 37 I.L.M. 999 (1998) [hereinafter ICC Statute].

2. See Steven Lee Myers, "U.S. Signs Treaty for World Court to Try Atrocities," N.Y. Times, Jan. 1, 2001, at A1.

3. William J. Clinton, "Statement on the Rome Treaty on the International Criminal Court," 37 Weekly Comp. Pres. Doc. 4 (Dec. 31, 2000), available at 2001 WL 14297016.

4. Jesse Helms, "Helms on Clinton Signature: This Decision Will Not Stand," Cong. Press Releases, Dec. 31, 2000, available at LEXIS, News Library, News Group File [hereinafter Helms, Decision]; see Letter of John R Bolton, Under Secretary of State for Arms Control and International Security, to U.N. Secretary General Kofi Annan, May 6, 2002, available at http://www.state.gov/r/pa/prs/ps/2002/9968.htm (visited May 7, 2002) [hereinafter Bolton letter] (stating "that the United States does 
This report will explore political and constitutional concerns underlying the U.S. position regarding the ICC. First it will review the history of U.S. involvement in the development of international criminal adjudication, before and after adoption of the ICC treaty. It then will present objections that U.S. opponents have voiced regarding the ICC Statute. Next it will examine areas in which that statute may conflict with the U.S. Constitution, among them prosecutorial power, immunity, rights of the accused, fugitive transfer, and imprisonment. Finally, it will discuss prospects for ratification of the ICC Statute. Legal obstacles to ratification may be surmountable, but not without significant political will to ratify, and that does not exist. The report thus concludes that the United States will neither ratify the ICC Statute, nor support the court, in the foreseeable future.

\section{History of U.S. INVOLVEMENT in InTERnAtional Criminal Adjudication}

In the post-World War II era, the United States was a leader in the development of international criminal adjudication. On the International Military Tribunals at Nürnberg and Tokyo, judges and prosecutors from the United States worked alongside their counterparts from other countries. U.S. military tribunals conducted additional trials. Thousands of individuals were tried for crimes against peace, crimes against humanity, and war crimes - offenses that, along with genocide, constitute the core crimes within the jurisdiction of the ICC. ${ }^{5}$

Even as the postwar trials were under way, there was a call to establish a permanent international criminal court within the framework of the nascent United Nations. ${ }^{6}$ That proposal languished until 1989, when a representative of Trinidad and Tobago sought reconsideration. ${ }^{7}$ The administration of Republican President George H.W. Bush expressed reservations, though it continued to push for transnational cooperation to combat drug-trafficking and terrorism. ${ }^{8}$ In

not intend to become a party" to the ICC treaty and that it thus "has no legal obligations arising from its signature").

5. See ICC Statute, supra n.1, arts. 5-8. On the postwar trials and the U.S. role, see generally Gary Jonathan Bass, Stay the Hand of Vengeance (2000); Telford Taylor, The Anatomy of the Nuremberg Trials (1993).

6. See Draft Proposal for the Establishment of an International Court of Criminal Jurisdiction, U.N. Doc. A/AC.10/21 (1947) (submitted by Henri Donnedieu de Vabres, French delegate to the General Assembly's Committee on the Progressive Development of International Law and its Codification, and formerly the French judge on the International Military Tribunal at Nürnberg).

7. See Letter from the Permanent Representative of Trinidad and Tobago to the United Nations addressed to the Secretary-General, U.N. GAOR, 44th Sess., U.N. Doc. A/44/195 (1989).

8. See Scharf, "Getting Serious about an International Criminal Court," 6 Pace Int'l L. Rev. 103, 103-05 (1994) (discussing views of first Bush Administration on ICC); Paul Lewis, "2 Big Powers Back World Court Role," N.Y. Times, Aug. 7, 1989, at 
1993, the administration of President Clinton, a Democrat, proclaimed the United States' "significant and positive interest" in an ICC. ${ }^{9}$ Thereafter, U.S. representatives helped to draft the statute that would be considered at a diplomatic conference in 1998 in Rome. The United States simultaneously assisted in drafting the statutes of the International Criminal Tribunal for the former Yugoslavia and the International Criminal Tribunal for Rwanda, ${ }^{10}$ and provided funds and staff once those ad hoc tribunals began operation. ${ }^{11}$ Then, at Rome, the United States joined six other states in voting against the ICC treaty.

After Rome, the Clinton Administration continued to negotiate at ICC preparatory sessions, but with the aim of insulating the United States from the effects of the treaty. Thus the U.S. delegation pushed for Elements of Crimes that narrowed the scope of the ICC Statute, and it lobbied in vain for a provision that would place U.S. nationals out of the reach of the court. ${ }^{12}$

Not everyone in the United States opposed the court. Some U.S. academics wrote favorably about the ICC Statute, ${ }^{13}$ and many U.S. nongovernmental organizations worked for ratification of the ICC treaty. ${ }^{14}$ Even the U.S. government offered a modicum of grudging

A5 (reporting on U.S.-Soviet agreement to accept binding arbitration of International Court of Justice in disputes over terrorism and drug-trafficking treaties and to try to persuade others to do same).

9. U.S. Mission to the United Nations, Statement by the Honorable Conrad K. Harper, United States Special Advisor to the United Nations General Assembly in the Sixth Committee, USUN Press Release \#171-(93) (Oct. 27, 1993), quoted in Scharf, supra n. 8 , at 109 .

10. See Statute of the International Tribunal for Rwanda, S.C. Res. 955, U.N. SCOR, 49th Sess., 3453d mtg., Annex, U.N. Doc. S/RES/955 (1994), reprinted in 33 I.L.M. 1598 (1994) [hereinafter ICTY Statute]; Statute of the International Criminal Tribunal for the Former Yugoslavia, S.C. Res. 827, U.N. SCOR, 48th Sess., 3217th mtg., Annex, U.N. Doc. S/RES/827 (1993), reprinted in 32 I.L.M. 1159 (1993) [hereinafter ICTR Statute].

11. See Wedgwood, "Improve the International Criminal Court," in Toward an International Criminal Court 53 (Alton Frye ed., 1999).

12. See Leigh, "The United States and the Statute of Rome," 95 Am. J. Int'l L. 124, 126-27 (2001) (discussing efforts to exempt U.S. nationals); Hall, "The First Five Sessions of the UN Preparatory Commission for the International Criminal Court," 94 Am. J. Int'l L. 773, 775-80 (2000) (discussing U.S. proposals on Elements).

13. See generally, e.g., Association of American Law Schools Panel on the International Criminal Court, 36 Am. Crim. L. Rev. 223, 238-43 (1999) (remarks of Dorean Marguerite Koenig); Bassiouni, "Negotiating the Treaty of Rome on the Establishment of an International Criminal Court," 32 Cornell Int'l L.J. 443 (1999); Meron, War Crimes Law Comes of Age, 92 Am. J. Int'l L. 462 (1998); Orentlicher, "Politics by Other Means: The Law of the International Criminal Court," 32 Cornell Int'l L.J. 489 (1999); Paust, "The Reach of ICC Jurisdiction Over Non-Signatory Nationals," 33 Vand. J. Transnat'l L. 1 (2000); Sadat \& Carden, "The New International Criminal Court: An Uneasy Revolution," 88 Geo. L.J. 381 (2000); Scharf, "The United States and the International Criminal Court: The ICC's Jurisdiction over the Nationals of Non-Party States: A Critique of the U.S. Position," 64 L. \& Contemp. Probs. 67 (2001); Diane Marie Amann, "A New International Spirit," S.F. Chron., Oct. 12, 2001, at A23.

14. See, e.g., Amnesty International USA, International Criminal Court, http:// www.amnestyusa.org/icd/ (visited Sept. 15, 2001); Human Rights Watch, Interna- 
support, signing the ICC treaty on Dec. 31,2000 , for the express purpose of maintaining influence over the court's development. Days later, President George W. Bush, a Republican, took office. His administration stepped up criticism of the ICC, and in May 2002 it carried out a plan for the United States to "unsign" the treaty. ${ }^{15}$ Earlier, Pierre-Richard Prosper, ambassador-at-large for war crimes issues, had said that the new administration did "support pursuing accountability for atrocities and war crimes as they occur around the world," 16 but not by means of a permanent international court. He advocated instead the establishment of additional temporary tribunals. ${ }^{17}$

Legislative initiatives illustrated the enduring and widespread opposition to the ICC within Congress. A law passed in 1999 prohibits use of U.S. funds to assist the ICC. ${ }^{18}$ An even harsher bill, called the American Servicemembers Protection Act of 2001, would bar any U.S. governmental entity from cooperating with the ICC; enjoin transfer to the ICC of "classified national security information"; deny military aid to many countries that join the ICC; forbid the use of U.S. troops in peacekeeping missions absent a grant of immunity by the U.N. Security Council; and allow the President to use "all means necessary and appropriate" to free U.S. soldiers arrested by the ICC. ${ }^{19}$ The bill has been approved in a number of bipartisan House votes, but has not cleared the Senate. ${ }^{20}$ The Bush Administration had opposed an effort to link the bill to U.S. payment of U.N. back dues; however, in late September 2001 it announced support for attaching the bill to "appropriate" legislation. ${ }^{21}$

tional Criminal Court, http://www.hrw.org/campaigns/icc/ (visited Sept. 15, 2001); Lawyers Committee for Human Rights, International Criminal Court: The Architecture of Global Justice, http://www.lchr.org/IJP/icc.htm (visited Sept. 15, 2001).

15. See Bolton letter, supra n. 4; Steven Mufson \& Alan Sipress, "U.N. Funds In Crossfire Over Court," Wash. Post, Aug. 16, 2001, at A1.

16. Pierre Prosper discusses the position of the US in prosecuting atrocities around the world (National Public Radio broadcast, All Things Considered, Aug. 2, 2001).

17. Norman Kempster, "U.S. May Back Creation of Special Atrocity Tribunals," L.A. Times, Aug. 2, 2001, at A1. See also Henry A. Kissinger, "The Pitfalls of Universal Jurisdiction," Foreign Affairs, July/Aug. 2001, at 86, 91 (calling for continued use of temporary tribunals until ICC Statute can be "renegotiate[d]").

18. Admiral James W. Nance and Meg Donovan Foreign Relations Authorization Act, Fiscal Years 2000 and 2001, $\S \S 705-06$, app. to Pub. L. 106-113 [H.R. 3427], 113 Stat. 1501 (1999).

19. American Servicemembers' Protection Act of 2001, H.R. 1794, 107th Cong. (2001).

20. In August 2001, 76 Democrats and 206 Republicans in the House of Representatives voted in favor of linking the bill to legislation that would authorize payment of $\$ 582$ million in back dues to the United Nations. Mufson \& Sipress, supra n. 15. A similar mix of representatives had approved the bill in May 2001, as part of the Foreign Relations Authorization Act for the 2002-03 fiscal year.

21. See Evelyn Leopold, "Bush Supports Helms Curbs on U.N. Criminal Court," Reuters Eng. News Serv., Sept. 28, 2001, available at Westlaw, allnewsplus. Earlier in the month the House sponsor of the bill had announced that he would delink it 
Also pending was the American Citizens' Protection and War Criminal Prosecution Act of 2001, which described a plan for "[c]ontinued United States engagement" with the ICC. ${ }^{22}$ This bill would authorize the United States, even as a nonparty, to give financial aid, legal assistance, and other support to the ICC "as appropriate, on a case-by-case basis," though it too would bar sharing of classified data. ${ }^{23}$ The United States would endeavor to investigate and prosecute all U.S. citizens and servicemembers suspected of crimes within the ICC's jurisdiction, and would not hand over to the ICC anyone who had been subjected to such proceedings. The bill also called for studies comparing the ICC Statute and U.S. laws, and conditioned ratification of the treaty on Presidential certification that the ICC is fair. Perhaps most significant is the fact that, though more moderate than the Servicemembers Protection Act, this bill also assumed that the United States ought not to join the ICC any time soon.

\section{U.S. Opposition to the ICC Statute}

The primary U.S. objections to the ICC Statute crystallized as early as a week after the Rome Conference, in hearings before a subcommittee of the Senate's Foreign Relations Committee. Senator Rod Grams opened the hearings by labeling the ICC treaty as not only "bad," but "dangerous," and declared "that the United States will not cede its sovereignty to an institution which claims to have the power to override the US legal system and pass judgment on our foreign policy actions."24 Strong words have characterized opposition ever since; examples include Senator Helms' description of the ICC as "this international kangaroo court,"25 Clinton Administration Ambassador David J. Scheffer's claim that one provision is "contrary to the most fundamental principles of treaty law;"26 and Senator Larry

from U.N. funding. See "DeLay to Drop His Opposition to Payment of U.N. Back Dues," Cong. Daily, Sept. 13, 2001, available at 2001 WL 2489053.

22. American Citizens' Protection and War Criminal Prosecution Act of 2001, S. 1296, 107th Cong., § 2(10) (2001). For support for this approach outside Congress, see Bill Richardson, “America's Interest in an International Court," N.Y. Times, Aug. 12, 2001 , at A17 (comment by former U.S. ambassador to the United Nations); "International Criminal Court, Hearing of the Senate Foreign Relations Comm.," Fed. News Serv., June 14, 2000 (statement of Yale Law Professor Ruth Wedgwood), available at 2000 WL 19305017 [hereinafter Wedgwood statement].

23. American Citizens' Protection and War Criminal Prosecution Act of 2001, supra n. $23, \S \S 7,8$.

24. Is a U.N. International Criminal Court in the National Interest?, Hearing on the International Criminal Court before the International Operations Subcomm. of the U.S. Senate Foreign Relations Cormm. (July 23, 1998) (statement of Senator Rod Grams), available at 1998 WL 12762521 [hereinafter Grams statement].

25. Helms, Decision, supra n. 3.

26. See U.N. International Criminal Court, Hearing on the International Criminal Court before the International Operations Subcomm. of the U.S. Senate Foreign Relations Comm. (July 23, 1998) (statement of David J. Scheffer, ambassador-at-large 
E. Craig's insistence that the ICC poses "a fundamental threat to American sovereignty."27

Though details may vary, specific U.S. objections cluster around a few themes. First, opponents ${ }^{28}$ assert that the ability of the ICC to bypass the Security Council would undermine the settled system of international governance and the U.S. role in that system. Second, they complain that the ICC prosecutor and judges, to be chosen in a manner U.S. opponents consider nondemocratic, would have undue authority to determine the ICC's jurisdiction, and thus may be tempted to launch politically motivated prosecutions. Third, opponents argue that the ICC Statute poses the risks of unfair trial proceedings. Taken as a whole, opponents contend, operation of the ICC as now structured is a menace to the sovereignty of the United States.

\section{A. The Security Council, the United States, and the ICC}

Like most countries, the United States is party to the half-century-old Charter of the United Nations, which imposes obligations that "shall prevail" over those under any other international agreement. ${ }^{29}$ The Charter establishes the Security Council as a "principal organ," with "primary responsibility for the maintenance of international peace and security ...."30 To that end, the Charter provides that the Council "shall determine the existence of any threat to the peace, breach of the peace, or act of aggression and shall . . . decide what measures shall be taken ...."31 The United States plays a key role, as one of five permanent members whose veto can thwart Security Council action. ${ }^{32}$

The proposed International Criminal Court would bypass this framework. Like the Security Council, the ICC would be interested

for war crimes issues and head of U.S. delegation at Rome), available at $1998 \mathrm{WL}$ 12762512 [hereinafter Scheffer statement].

27. Larry E. Craig, "Under the U.N. Gavel," Wash. Post, Aug. 22, 2001, at A19. See also Grams statement, supra n. 24 ("I hope that now the Administration will actively oppose this Court to make sure that it shares the same fate as the League of Nations - and collapses without US support. For this Court truly is a monster, and it is a monster that must be slain.").

28. Although this report speaks collectively of "opponents" or "critics," of course not all of them share all stated concerns or all tactics for blocking the ICC. For instance, one commentator questioned the ICC Statute, Michael J. Glennon, "There's a Point to Going It Alone," Wash. Post, Aug. 12, 2001, at B02, yet also argued that total noncooperation with the ICC, as would be required by the American Servicemembers' Protection Act, supra n. 19, could work against U.S. interests. See Mufson \& Sipress, supra n. 15 (quoting Glennon as saying, "We should make it easier, not harder, for other nations to investigate and arrest thugs who commit crimes against Americans.").

29. U.N. Charter, art. 103.

30. Id., arts. 7(1), 24(1).

31. Id., art. 39.

32. Id., arts. 23(1), 27(3). 
in matters affecting international peace and security - initially, war crimes, genocide, and crimes against humanity; eventually, aggression and perhaps even terrorism and drug-trafficking. ${ }^{33}$ It could look into such matters even without a Security Council request. ${ }^{34}$ The Council could postpone investigations, but only if all permanent members, and a majority of the nonpermanent members, agreed..$^{35}$

Pointing to these provisions, U.S. opponents argue that all matters of interest to the ICC fall within the jurisdiction of the Security Council; therefore, the Council should have prior review before a matter is referred to a judicial process. ${ }^{36}$ Without such review, opponents maintain, the ICC would deprive permanent members of their veto and could trespass on the Security Council's domain. ${ }^{37}$ Furthermore, the ICC Statute extends jurisdiction to nationals of nonparty states who are accused of crimes committed on the territory of states parties. ${ }^{38}$ Opponents predict that this state of affairs will pose a significant deterrent to military action, including U.N. peacekeeping operations, that are necessary to protect international peace and se-

33. The statute lists the crime of aggression as within the ICC's jurisdiction, though it may not be prosecuted until after the Assembly of States Parties formulates a definition of aggression. ICC Statute, supra n. 1, arts. 5, 121, 123. On the possible addition of drug-trafficking and terrorism, see Final Act of the United Nations Diplomatic Conference of Plenipotentiaries on the Establishment of an International Criminal Court, U.N. Doc. AVCONF.183/10* (July 17, 1998), annex I, discussed in McConville, "Note, A Global War on Drugs: Why the United States Should Support the Prosecution of Drug Traffickers in the International Criminal Court," $37 \mathrm{Am}$. Crim. L. Rev.75, 93-94 \& n. 138 (2000).

34. See ICC Statute, supra n. 1, arts. 13-15 (permitting exercise of jurisdiction not only on Security Council referral, but also on request of a state party or on prosecutor's own initiative).

35. ICC Statute, supra n.1, art. 16 (allowing twelve-month deferral of investigation or prosecution, renewable indefinitely, pursuant to Security Council resolution). As it stands, the veto power could work to the disadvantage of the United States. If another permanent member - say, China - wished, it could permit ICC investigation of a U.S. national simply by vetoing any resolution for deferral.

36. See Scheffer statement, supra $n$. 26 ("There will necessarily be cases where the international court cannot and should not have jurisdiction unless the Security Council decides otherwise."). This position also had been raised at the outset of the Rome Conference. See Ruth Wedgwood, "The Pitfalls of Global Justice," N.Y. Times, June 10, 1998, at A29.

37. See Grams statement, supra n. 24 (stating that today "international law regarding peace and security is . . . whatever the Security Council says that it is," but expressing concern that "[w]ith the creation of the International Criminal Court, that will no longer be the case" because of reversal of veto power); U.N. International Criminal Court, Hearing on the International Criminal Court before the International Operations Subcomm. of the U.S. Senate Foreign Relations Comm. (July 23, 1998) (statement of Sen. Jesse Helms), available at 1998 WL 12762482 [hereinafter Helms statement] (declaring that ICC statute "represents a massive dilution of the UN Security Council's powers - and of the United States' veto power within the Security Council").

38. See ICC Statute, supra n. 1, art. 2(a). Among those who has criticized this provision, a form of universal jurisdiction, is a former U.S. Secretary of State whom individuals in some countries have attempted to subject to criminal process based on this same universality principle. See generally Kissinger, supra n. 17. 
curity. ${ }^{39}$ Pending legislation, which would restrict U.S. participation in peacekeeping, circumscribe U.S. military aid to ICC member states, and authorize the use of force to release U.S. nationals held in ICC custody, reflects these concerns. ${ }^{40}$

\section{B. ICC Jurisdiction and Risk of Politically Motivated Prosecution}

Fueling objections to the diminished authority of the Security Council are some opponents' fears that nondemocratic governments could control the personnel and activities of the ICC. Each state party to the ICC is to have one vote in the Assembly of States Parties, ${ }^{41}$ the body empowered to choose and to remove the prosecutor and judges; ${ }^{42}$ to adopt Elements of Crimes and Rules of Procedure and Evidence; 43 and to amend the ICC Statute. ${ }^{44}$ At the post-Rome congressional hearings, Senator Grams argued that because of this governance structure, ICC decision-making "will not be confined to those from democratic countries with the rule of law." 45

This argument gives rise to the oft-repeated concern that the ICC will pursue politically motivated prosecutions. ${ }^{46}$ Any state party would be able to ask for investigation into a matter, or the prosecutor may open an investigation on her or his own initiative; that is,

39. See Grams statement, supra n. 24 (maintaining arguing that the "most effective deterrent" to international crimes "is the threat of military action - and this Court is undermining the ability of the United States to do that very thing"); Scheffer statement, supra n. 26 (stating that possible application of the statute to U.S. soldiers regardless of ratification could "inhibit the ability of the United States to use its military to meet alliance obligations and participate in multinational operations, including humanitarian interventions to save civilian lives").

40. American Servicemembers' Protection Act of 2001, supra n. 19.

41. ICC Statute, supra n. 1, art. 112.

42. See id., art. 36(6)(a) (providing that Assembly may choose judges by a twothirds majority of present, voting members); id., art. 46(2)(a) (allowing removal of judges by two-thirds majority of states parties, on recommendation by two-thirds of other judges); id., art. 42(4) (providing for choice of prosecutor by vote of "absolute majority" of members); id., art. 46(2)(b) (permitting removal of prosecutor by "absolute majority" of states parties).

43. Id., art. 9(1) (permitting adoption of Elements of Crimes by a two-thirds majority of members); id., art. 51(1) (authorizing adoption of procedural rules by same margin).

44. See id., arts. 121, 122 (providing for amendment by two-thirds majority of states parties); id., art. 5(2) (authorizing eventual addition of crime of aggression pursuant to statute's amendment procedures).

45. Grams statement, supra n. 24 (speaking specifically of ICC judges). Cf. U.N. International Criminal Court, Hearing on the International Criminal Court before the International Operations Subcomm. of the U.S. Senate Foreign Relations Comm. (July 23, 1998) (written statement of Lee A. Casey \& David B. Rivkin, Jr.), available at 1998 WL 12762551 hereinafter Casey \& Rivkin statement) (contending that ICC would be unaccountable to U.S. citizens even if United States joined).

46. See Grams statement, supra n. 24; U.N. International Criminal Court, Hearing on the International Criminal Court before the International Operations Subcomm. of the U.S. Senate Foreign Relations Comm. (July 23, 1998) (statement of John R. Bolton), available at $1998 \mathrm{WL} 12763220$ [hereinafter Bolton statement]. 
proprio motu. ${ }^{47}$ Opponents have maintained that because a majority of the Assembly of States Parties will select and may fire the prosecutor, the character and motivations of the prosecutor will reflect the character and motivations of a majority of states parties. ${ }^{48}$ They feared the possibility that one day the prosecutor, without prior Security Council review, might be allowed to pursue charges of aggression, as defined not by the Council but by the Assembly of States Parties. ${ }^{49}$ The breadth of prosecutorial power, coupled with the asserted fear that the prosecutor will be subordinated to the states parties, are pivotal to the politicization objection. ${ }^{50}$

Safeguards against such abuse appear in the ICC Statute. A proprio motu investigation could be stopped by vote of two judges in the ICC's Pre-Trial Chamber. ${ }^{51}$ According to the principle of complementarity, moreover, ICC judges could not deem a case admissible as long as a state was "willing" or able "genuinely to prosecute" the case. 52 "Unwillingness" is to be measured by "unjustified delay" or lack of sufficient "impartiality" or "independence" in the proceedings. ${ }^{53}$ The United States thus should be able to shield its nationals from the ICC by undertaking a good-faith investigation and, if appropriate, prosecution. These safeguards have not assuaged U.S. critics, who have argued that the judges themselves will be subject to selection and removal by the governments of nondemocratic states parties.

The ICC Statute permits each member state to put forward one candidate to compete for eighteen ICC judgeships. Candidates must

47. ICC Statute, supra n.1, arts. 13(a), (c), 14, 15. The third method for opening a matter is by Security Council referral, discussed supra $\S$ II(A).

48. See Casey \& Rivkin statement, supra n. 45 ("The United States has interests and responsibilities around the world and the possibility that a prosecutor and bench staffed by individuals hostile to the United States or its interests is quite real. The Cold War is over, but the United States still has enemies and competitors. Indeed, as the World's only superpower, it is viewed with suspicion by many states, and with outright hostility by more than a few. All would have an equal vote in selecting the ICC's personnel if they choose to ratify the treaty.").

49. Helms statement, supra n. 37 "I think I can anticipate what will constitute a crime of aggression in the eyes of this Court. It will be an act of aggression whenever the United States of America takes any military action to defend the national interest of the American people unless the United States first seeks and receives the permission of the United Nations."); Scheffer statement, supra n. 26 (arguing that prosecution for aggression ought to require a previous determination of aggression by the Security Council).

50. See Grams statement, supra n. 24 (stating that ICC Statute provides "no effective screen against politically motivated prosecutions"); Scheffer statement, supra n. 26 (asserting that authorizing prosecutor to self-initiate investigations threatens to mire ICC in political controversy); Helms statement, supra $n$. 37 (complaining that prosecutor would be "accountable to no state or institution for his actions"); Kissinger, supra $n$. 17, at 90-91 (criticizing extent of prosecutorial discretion).

51. ICC Statute, supra n. 1, art. 15(3).

52. Id., art. 17. For proclamations of the principle of complementarity, see id., pmbl., art. 1.

53. Id., art. 17(2)(c). 
be "persons of high moral character, impartiality and integrity who possess the qualifications required in their respective States for appointment to the highest judicial offices." ${ }^{4}$ In the view of some U.S. opponents, relying on standards within states, especially those that are nondemocratic, sets too low a threshold. ${ }^{55}$ Out of this mistrust of the independence and competence of those who would become ICC judges arise, not surprisingly, complaints that the statute gives final say on the extent of the ICC's jurisdiction ${ }^{56}$ and on the propriety of the prosecutor's actions to these same judges. ${ }^{57}$

\section{Due Process Concerns}

ICC institutions - the judiciary, the prosecutor, and the Assembly of States Parties - also have final say regarding the procedures the court will follow. To a large extent the ICC Statute comprehends the rights of the accused that are honored in the United States; indeed, a representative of the American Bar Association has told Congress that "the Treaty of Rome contains the most comprehensive list of due process protections which has so far been promulgated." 58 Still, there are differences, most notably, the absence of any right to trial by jury. These have prompted opponents to argue that ICC trials would violate U.S. standards. ${ }^{59}$

\section{State Sovereignty and the ICC}

Underlying all these objections is the claim that the ICC structure is less democratic, and so less independent, than U.S. domestic

54. Id., art. $36(1),(3)(a),(4)(b)$.

55. See Grams statement, supra n.24.

56. See Craig, supra n.27 (stating that "the court's stated mission is dealing with war crimes and crimes against humanity - which, because there is no appeal from its decisions, only the court will have the right to define"); see also ICC Statute, supra n.1, art. 119 ("Any dispute concerning the judicial functions of the Court shall be settled by the decision of the Court.").

57. See Grams statement, supra n. 24.

58. House Comm. on Int'l Relations, July 25, 2000 (prepared testimony of Monroe Leigh), available in Fed. News Serv., July 25,2000 [hereinafter Leigh testimony]. See infra § III(D) (analyzing rights of accused before ICC).

59. See U.N. International Criminal Court, Hearing on the International Criminal Court before the International Operations Subcomm. of the U.S. Senate Foreign Relations Comm. (July 23, 1998) (statement of then-Sen. John Ashcroft, now U.S. Attorney General), available at 1998 WL 12762510 (“[N]o aspect of this Court is more troubling than the fact that it has been framed without any apparent respect for indeed, in direct contravention of - the United States Constitution."); Helms statement, supra n. 37 (stating that treaty would undermine guarantees of U.S. Bill of Rights); Craig, supra n. 27. See also American Servicemembers' Protection Act of 2001, supra n. 19, § 2(6) ("Any American prosecuted by the International Criminal Court will, under the Rome Statute, be denied procedural protections to which all Americans are entitled under the Bill of Rights to the United States Constitution, such as the trial by jury."). 
political and judicial institutions. ${ }^{60}$ In the past the United States has bridged differences between an international arrangement and internal practice by various means. A favored method has been to ratify a treaty subject to reservations that conformed U.S. treaty obligations to the constraints of the U.S. Constitution. ${ }^{61}$ The United States sought the same leeway at Rome; nonetheless, the treaty contains an explicit ban on reservations. ${ }^{62}$ Likewise, it failed to persuade conferees to permit states parties to avoid ICC prosecution for some crimes during a so-called opt-out period. ${ }^{63}$ Finally, of course, the United States lost the considerable influence it might have had if the ICC had been subordinated to the Security Council. These losses, opponents argue, forebode an ICC that could work to the detriment of U.S. soldiers and U.S. sovereignty.

\section{The U.S. Constitution and the ICC Statute}

Opponents' objections to the International Criminal Court intermingle basic questions about the court's assertedly undemocratic foundations with concerns about specific legal and constitutional restraints. This report now focuses on these latter concerns, considering whether U.S. law clashes with the ICC Statute, in the discrete areas of prosecutorial power, immunity and other legal barriers to prosecution, defense rights, surrender of fugitives, and imprisonment. ${ }^{64}$ It then examines whether the U.S. constitutional framework would allow reconciliation with the ICC Statute.

60. See Bolton statement, supra n. 46 (arguing that ICC Statute lacks checks and balances to be expected in a constitutive document).

61. See, e.g., U.S. Reservations, Understandings, and Declarations, International Covenant on Civil and Political Rights, nos. I(1-3), II(1), III(2), IV, 138 Cong. Rec. 8068 (1992). The U.S. practice of conditioning membership in treaty regimes has provoked controversy. See generally Schabas, "Invalid Reservations to the ICCPR: Is the United States Still a Party?," 21 Brooklyn J. Int'l L. 227 (1995).

62. ICC Statute, supra n. 1, art. 120; see Scheffer statement, supra note 26 (objecting to the ban on reservations). Cf. Bolton statement, supra $n$. 46 (stating that approval of the ICC Statute would undercut reservations U.S. made when ratifying Genocide Convention).

63. See Scheffer statement, supra n. 26 (describing unsuccessful U.S. bid for "10year transitional period" when states parties could choose to shield their nationals from prosecution for crimes against humanity or war crimes). The ICC Statute does provide a seven-year opt-out period for war crimes. See ICC Statute, supra n. 1, art. 124; Amann, "Harmonic Convergence? Constitutional Criminal Procedure in an International Context," 75 Ind. L.J. 809, 863 (2000) (explaining how this provision satisfied French demands) [hereinafter Amann, Convergence].

64. This article looks only at the ICC Statute itself. It does not review any definition of aggression nor proposed Elements of Crimes or Rules of Procedure and Evidence, all of which await consideration and approval of at least two-thirds of the Assembly of States Parties. See ICC Statute, supra n.1, arts. 9(1), 51(1), 121, 122. 


\section{A. Prosecutorial Power}

Aiming to "put an end to impunity" for those who commit "the most serious crimes of concern to the international community," 65 the ICC Statute confers on the prosecutor significant powers. In addition to being able to self-initiate an investigation, ${ }^{66}$ in some circumstances, the prosecutor would be permitted to gather evidence inside a state's territory yet outside the presence of authorities of that state. ${ }^{67}$ The Constitution authorizes Congress to enact laws, including those that "define and punish . . . Offences against the Law of Nations," and the President to execute those laws. ${ }^{68}$ It gives the President and the Senate joint responsibility for concluding treaties. ${ }^{69}$ Nothing in the Constitution forbids conclusion of a treaty or other agreement that cedes some investigative authority. ${ }^{70}$ In point of fact, the United States has spearheaded joint ventures in law enforcement that share investigation with authorities in other nationstates. $^{71}$

\section{B. Official Immunity}

Article 27 of the ICC Statute deprives officials of any immunity they may enjoy "under national or international law."72 Thus, the ICC may exercise jurisdiction over a person regardless of "official capacity as a Head of State or Government, a member of a Government or parliament, an elected representative or a government official," and such status alone does not justify a lesser sentence. ${ }^{73}$ The provision builds on less detailed but similar ones in the laws that governed the trials at Nürnberg and Tokyo, ${ }^{74}$ in the Genocide Convention, ${ }^{75}$

65. Id., pmbl.

66. See id., art. 15.

67. See id., art. 99(4).

68. U.S. Const., arts. I, § 8, II.

69. Id., art. II, $\$ 2$ (stating that the President "shall have Power, by and with the Advice and Consent of the Senate, to make Treaties").

70. Accord Benison, "International Criminal Tribunals: Is There a Substantive Limitation on the Treaty Power?," 37 Stan. J Int'l L. 75, 107-11 (2001) (drawing analogy between ICC prosecutor and independent prosecutor within United States, concludes that Constitution does not forbid ceding authority to ICC prosecutor).

71. See Amann, Convergence, supra n. 63, at 820-21 (describing U.S. role in international law enforcement cooperation); Amann, "A Whipsaw Cuts Both Ways: The Privilege Against Self-Incrimination in an International Context," 45 UCLA L. Rev. 1201, 1261-65 (1998) (same) [hereinafter Amann, Whipsaw].

72. ICC Statute, supra n. 1, art. 27.

73. Id.

74. Agreement for the Prosecution and Punishment of the Major War Criminals of the European Axis Powers and Charter of the International Military Tribunal, Aug. 8,1945 , art. 7, 59 Stat. 1544, 82 U.N.T.S. 279 ("The official position of defendants, whether as Heads of State or responsible officials in Government Departments, shall not be considered as freeing from responsibility or mitigating punishment."); Allied Control Council Law No. 10: Punishment of Persons Guilty of War Crimes, Crimes Against Peace and Against Humanity, art. II(4)(a), Dec. 20, 1945, 3 Official Gazette of the Control Council of Germany 50 (1946) (similar regarding guilt, but permitting as 
and in the statutes of the ad hoc tribunals. ${ }^{76}$ Nonetheless, the stripping of official immunity runs counter to the plain text of numerous national constitutions. ${ }^{77}$

The U.S. Constitution contains no express grant of official immunity. The U.S. Supreme Court, however, has interpreted the Constitution to confer on the President and other governmental representatives certain immunities from legal process. ${ }^{78}$ The President enjoys "absolute immunity from civil damage actions arising out of the execution of official duties of office," extending to the "outer perimeter of his authority."79 The President may, however, be made to answer a civil lawsuit that challenges actions taken before assuming office. ${ }^{80}$ Likewise, the President may be required to give evidence, particularly in a criminal case in which the "fair administration of justice" so demands. ${ }^{81}$

Whether a President is immune from penal responsibility has never been tested in the courts, though it was a subject of debate in the tumultuous final years of the Clinton Administration. The Constitution posits impeachment as a mechanism for dealing with misconduct by the President and other governmental officials. Both the legislature and the judiciary have roles: the House of Representatives has the sole power of impeachment, for trial by the Senate, with the Chief Justice of the United States presiding. The Constitution specifies that the penalty for conviction on impeachment charges

shall not extend further than to removal from Office, and disqualification to hold and enjoy any Office of honor, Trust or Profit under the United States: but the Party convicted

defense in mitigation of punishment); International Military Tribunal for the Far East at Tokyo, April 26, 1946, art. 6, T.I.A.S. No. 1589, 4 Bevans 20 (similar to Control Council Law No. 10).

75. Convention on the Prevention and Punishment of the Crime of Genocide, art. IV, Dec. 9, 1948, 78 U.N.T.S. 277 ("Persons committing genocide or any of the other acts enumerated in article III shall be punished, whether they are constitutionally responsible rulers, public officials or private individuals.") [hereinafter Genocide Convention].

76. See ICTY Statute, supra n.10, art. 7(2); ICTR Statute, supra note 10, art. 6(2).

77. See, e.g., Cons. const., Jan. 22, 1999, J.O., Decision No. 98-408 D.C., 1317, available at $\mathrm{http}: / / \mathrm{www}$.conseil-constitutionnel.fr/decision/1998/98408/98408dc.htm (declaring that the ICC Statute is contrary to the immunity granted the President and other officials in Articles 26, 68, and 68-1 of the French Constitution). See generally Duffy, "National Constitutional Compatibility and the International Criminal Court," 11 Duke J. Comp. \& Int'l L. 5 (2001) (citing similar provisions in other national constitutions).

78. In sundry opinions the U.S. Supreme Court has extended immunities to a variety of officials, including prosecutors, legislators, judges, and federal officials. See Clinton v. Jones, 520 U.S. 681,693 n.18 (1997). This report discusses only the potential immunity of the President, who enjoys the greatest constitutional protection.

79. Nixon v. Fitzgerald, 457 U.S. 731, 756-57 (1982).

80. Clinton, 520 U.S. at $692-93$.

81. United States v. Nixon, 418 U.S. 683, 709-12 (1974) (requiring President to obey subpoena to produce recordings of conversations with aides). 
shall nevertheless be liable and subject to Indictment, Trial,

Judgment and Punishment, according to Law."82

Some scholars derived from the placement of the last clause, coupled with historical considerations, a constitutional rule forbidding criminal prosecution unless and until a President is removed from office following conviction for impeachment. ${ }^{83}$ Disputing this interpretation, others maintained that impeachment and prosecution are independent processes, and that nothing in the Constitution bars prosecution of an incumbent President. ${ }^{84}$

The U.S. Constitution, therefore, provides immunity, but with significant qualifications. The impeachment provisions may be interpreted to block exercise of criminal jurisdiction over a sitting President, although there is disagreement on this point. There appears to be no bar to prosecution of former Presidents. Indeed, if the President leaves office on account of removal after conviction on impeachment charges, the Constitution explicitly permits criminal proceedings, without reference to where they might occur. Should the ICC secure personal jurisdiction - an important caveat ${ }^{85}$ - the Constitution would not appear to bar ICC prosecution of a former President, or even, applying the view of some U.S. scholars, of an incumbent President.

\section{Amnesty and Pardon}

Another legal means to escape domestic prosecution and punishment, much debated in the context of the ICC, is amnesty. The ICC Statute says nothing about whether, and under what circumstances, a domestic grant of amnesty might preclude the ICC from exercising jurisdiction over an individual. Some scholars have argued that this silence would permit the ICC to respect grants of amnesty; others, that it would not. ${ }^{86}$ In any event, the question would not seem to

82. U.S. Const., art. I, § 3.

83. E.g., Impeachment or Indictment Possibilities, Hearings Before the Subcomm. on the Constitution, Federalism, and Property Rights of the Senate Comm. on the Judiciary (Sept. 9, 1998) (statement of Susan Low Bloch), available at 1998 WL 18089606; Amar, “On Prosecuting Presidents," 27 Hofstra L. Rev. 671 (1999); Bybee, "Who Executes the Executioner?," 2 Nexus 53 (1997). Cf. Isenbergh, "Impeachment and Presidential Immunity from Judicial Process," 18 Yale L. \& Pol'y Rev. 53 (1999) (criticizing Supreme Court's immunity jurisprudence, and arguing that President should be immunized from civil as well as criminal judicial process).

84. E.g., Freedman, "On Protecting Accountability," 27 Hofstra L. Rev. 677 (1999); Turley, "From Pillar to Post': The Prosecution of American Presidents," 37 Am. Crim. L. Rev. 1049 (2000). See Rotunda, "The True Significance of Clinton v. Jones," Chi. Trib., July 8, 1997, at 13 (contending that a sitting President can be indicted, but perhaps not incarcerated).

85. See infra $\S \mathrm{III}(\mathrm{G})$.

86. See Dugard, "Dealing with Crimes of a Past Regime. Is Amnesty Still an Option?," 12 Leiden J. Int'l L. 1001, 1013-15 (1999) (summarizing debate) see generally Young, Comment, "Amnesty and Accountability," 35 U.C. Davis L. Rev. 427 (2002) (proposing framework for ICC consideration of amnesties). 
pertain in the United States. Amnesty often arises out of peace agreements that settle internal conflicts or as part of a transition from dictatorship to democracy, and neither context applies to the United States today. ${ }^{87}$

There is, however, a relevant and contemporary U.S. corollary: the Presidential pardon. A notable use of this power occurred in 1974, when President Gerald Ford pardoned his predecessor, Richard M. Nixon. One might ask whether, had the ICC been in existence, the pardon alone would have shielded Nixon from international scrutiny for activities as Commander in Chief during the Vietnam War and the coup in Chile. ${ }^{88}$ At first glance, the answer would seem to be no. The Constitution explicitly limits the pardon power to "Offences against the United States"; 89 it says nothing about the international crimes that would fall within the ICC's jurisdiction. Yet some acts of genocide, torture, and war crimes already are proscribed by U.S. law, and other international offenses could be added. ${ }^{90} \mathrm{~A}$ court might well deem such acts offenses against the United States, and thus within the purview of the pardon power.

\section{Criminal Procedure and Rights of the Accused}

The ICC Statute reflects international movement toward criminal procedures that respect defendants' rights. ${ }^{91}$ On establishment of "grounds to believe that a person has committed a crime within the jurisdiction of the Court," questioning of the person, whether or not in custody, must be proceeded by warnings like those that the U.S. Supreme Court set forth in Miranda $v$. Arizona. ${ }^{92}$ An accused enjoys the presumption of innocence, ${ }^{93}$ and the prosecution must shoulder the burden of proof "beyond reasonable doubt" at all

87. See, e.g., ECOWAS: Peace Agreement between the Government of Sierra Leone and the Revolutionary United Front of Sierra Leone (RUF/SL) - Lome, 7 July 1999, art. IX, reprinted in 11 Afr. J. Int'l \& Comp. L. 557, 563 (1999) (granting amnesty to unnamed combatants and full pardon to leader of rebels during civil war); Dugard, supra n. 86, at 1009-13 (comparing amnesties granted by successor regimes in South Africa and Chile). The United States did grant amnesties after the Civil War of the mid-nineteenth century. See J.G. Randall \& David Herbert Donald, The Civil War and Reconstruction 560-61 (2d ed. 1969).

88. A recent book argues that Nixon's Secretary of State ought to be prosecuted for involvement in those events. Christopher Hitchens, The Trial of Henry Kissinger 25-43, 55-76 (2001).

89. U.S. Const., art. II, $\S 2$.

90. See Genocide Convention Implementation Act of 1987, 18 U.S.C. $\S \S 1091-93$; War Crimes Act of 1996 , codified as amended, 18 U.S.C. $\S 2441$ (2000); 18 U.S.C. $\$ 2340-2340$ (2000) (making torture a U.S. crime). See also infra $\S$ III(G) (discussing advisability of reconciling U.S. and ICC law as means of exploiting complementarity).

91. See Amann, Convergence, supra n. 63, at 811-45.

92. 384 U.S. 436, 444 (1966); ICC Statute, supra n. 1, art. 55(2). To this extent the ICC Statute provides greater protection than the Constitution, as the latter requires such warnings only if an interrogee is in custody. See Dickerson v. United States, 530 U.S. 428, 431-32 (2000).

93. ICC Statute, supra n.1, art. 66. 
stages. ${ }^{94}$ There is a right to bail. ${ }^{95}$ Also guaranteed are a fair, impartial, speedy, and public hearing; detailed information regarding the charges; adequate preparation of a defense; free, confidential communication with counsel of choice; presence at trial; the right to conduct a defense personally or through counsel, appointed if necessary; the rights to examine opposing witnesses and obtain testimony of favorable witnesses; an interpreter; and the right to decline to testify without having silence used as a factor in determination of a verdict. ${ }^{96}$

Yet the procedures in the statute do not mirror those familiar to U.S. practitioners of criminal law. Some entitlements do not appear as positive rights of an accused, but rather must be inferred from descriptions of prosecutorial responsibilities. ${ }^{97}$ The ICC Statute omits a hallmark of U.S. criminal litigation, the protection against unreasonable searches and seizures. ${ }^{98}$ Furthermore, its guarantee of witness examination may be qualified more than application of the U.S. constitutional right to confrontation would allow. ${ }^{99}$ This has been the case with the ICTY. In a ruling at odds with U.S. law, the ICTY permitted the prosecution to withhold from the defense the identities of certain witnesses. ${ }^{100}$ And the ICTY is moving toward a use of written evidence that troubled one of its own members, a former U.S. federal judge. ${ }^{101}$

Perhaps most striking is the absence of a jury. As with the ad hoc tribunals, ICC verdicts are to be based on the majority vote of a panel of three judges. ${ }^{102}$ Either side may appeal the verdict. ${ }^{103}$ ICTY experience demonstrates, moreover, that prosecutorial appeal

94. Id., art. 66(3), 67(i).

95. Id., art. $60(2)$.

96. Id., art. 67.

97. E.g., id., art. 55 (describing what warnings prosecutor must accord suspect before questioning). See also "International Criminal Court," $36 \mathrm{Am}$. Crim. L. Rev. 223, 236 (1999) (remarks of Christopher L. Blakesley).

98. See U.S. Const., amend. IV. The statute does permit exclusion of illegally obtained evidence in some circumstances. See ICC Statute, supra n. 1, art. 69(7).

99. Compare ICC Statute, supra n.1, art. 67(1)(e) ("the accused shall be entitled . [t]o examine, or have examined, the witnesses against him or her"), with U.S. Const., amend. VI ("the accused shall enjoy the right . . . to be confronted with the witnesses against him").

100. Compare Prosecutor v. Tadić, Case No. IT-94-1-T, 105 I.L.R. 519, Trial Chamber Decision on the Prosecutor's Motion Requesting Protective Measures (Aug. 10, 1995), reprinted in 7 Crim. L.F. 139 (1996), with Alvarado v. Superior Court, 23 Cal. 4th 1121, 5 P.3d 203, 99 Cal. Rptr. 2d 149 (2000), cert. denied, 532 U.S. 990 (2001). See Amann, Convergence, supra n. 63, at 849 n.252 (discussing controversy surrounding Tadić ruling). The tribunal relied on a statutory protection of witnesses comparable to that which would bind the ICC. Compare ICTY Statute, supra n. 10, art. 22, with ICC Statute, supra n. 1, art. 68.

101. See Patricia M. Wald, "To "Establish Incredible Events by Credible Evidence": The Use of Affidavit Testimony in Yugoslavia War Crimes Tribunal Proceedings," 42 Harv. Int'l L.J. 535, 549-52 (2001).

102. ICC Statute, supra n. 1, arts. 34, 39(2)(b)(ii), 74.

103. Id., art. 81(1). 
of an acquittal may result in imposition of a guilty verdict by appellate judges who did not witness the trial. ${ }^{104}$ Some of these procedures deviate from those guaranteed a defendant in a U.S. courtroom. The Constitution guarantees to any defendant charged with a serious crime the right to trial by jury. ${ }^{105}$ The right of appeal by the prosecutor would seem to infringe on both the province of the jury and the common-law understanding of double jeopardy. ${ }^{106}$ Still, the Constitution permits limits on the jury-trial right. Constituent states may secure conviction with a non-unanimous jury verdict. ${ }^{107}$ A person may suffer court-martial based on two-thirds agreement of a military judge and five members. ${ }^{108}$ Moreover, the Constitution guarantees defendants jury trials "in the State and district wherein the offense shall have been committed," a provision that seems not to apply to trials outside the United States. ${ }^{109}$

\section{E. Sentencing and Imprisonment}

In the United States, conviction for many drug offenses carries mandatory minimum sentences of twenty years; conviction for some offenses mandates life imprisonment. ${ }^{110}$ For certain murders and other heinous crimes, U.S. statutory law permits the death penalty. ${ }^{111}$ U.S. statutes further authorize life imprisonment or capital punishment for persons convicted of genocidal killing or of war crimes or torture resulting in death. ${ }^{112}$ Clearly, the sentencing contemplated in the ICC Statute - imprisonment for up to thirty years

104. See Prosecutor v. Tadić, Case No. IT-94-1-T, Appeals Chamber Judgement, para. 327(4), (5) (July 15, 1999) (reversing Trial Chamber findings of acquittal and entering guilty verdicts on nine counts).

105. See U.S. Const., amend. VI; Duncan v. Louisiana, 391 U.S. 145, 149-50 (1968).

106. See U.S. Const., amend. V' "nor shall any person be subject for the same offence to be twice put in jeopardy of life or limb"); Wedgwood statement, supra n. 22 (discussing areas of constitutional concern, with particular mention of prosecutor's right of appeal). Clouding analysis here is the fact that even though many international law instruments guarantee a right to appeal, e.g., International Covenant on Civil and Political Rights, art. 14(5), G.A. Res. 2200, U.N. GAOR, 21st Sess., Supp. No. 16, at 49, U.S. precedent holds that none is required by the Constitution. See Smith v. Robbins, 528 U.S. 259, 271 n.5 (2000) (restating holding of McKane v. Durston, 153 U.S. 684 (1894), that there is no constitutional right to an appeal).

107. See Johnson v. Louisiana, 406 U.S. 356, 354 (1972) (holding that Constitution allows conviction by agreement of nine of twelve jurors).

108. Manual for Courts-Martial, United States (1998 ed.), Rules 201(f)(1)(B), 921(c), 501.

109. U.S. Const., amend VI; see Leigh testimony, supra n. 58.

110. See Harmelin v. Michigan, 501 U.S. 957, 1009 (1991) (holding that U.S. Constitution permitted mandatory sentence of life without possibility of parole for possession of 650 grams of cocaine).

111. Federal Death Penalty Act of 1994,18 U.S.C. $§ 3591$ et seq. (2000); see Little, "The Federal Death Penalty: History and Some Thoughts about the Department of Justice's Role," 26 Fordham Urb. L.J. 347, 389-99 (1999) (questioning constitutionality of execution for crimes not involving homicide).

112. See 18 U.S.C. $\S 1091(b)(1)$ (genocide); id., § 2441 (war crimes); id., §2340A(a) (torture). 
or, in exceptional circumstances, for life $\mathrm{e}^{113}$ - poses no conflict with U.S. legal tradition.

As for incarceration, Article 106 of the ICC Statute requires that conditions of confinement "be consistent with widely accepted international treaty standards governing the treatment of prisoners." 114 The same article also states, however, that such conditions "shall be governed by the law of the State of enforcement," and "in no case" shall they "be more or less favourable than those available to prisoners convicted of similar offences in the State of enforcement."115 Observing that "in practice, prison conditions vary widely," one U.S. commentator has voiced concern that detention and confinement might not meet "the relatively high standards" of the United States and other Western countries. ${ }^{116}$

\section{F. Surrender of Fugitives}

On issuance of a proper arrest warrant, the ICC Statute obligates a state party to "surrender" a person who has sought asylum within the state. ${ }^{117}$ The statute uses the word "surrender," defined as "the delivering up of a person by a State to the Court," in lieu of the more familiar "extradition," defined as "the delivering up of a person by one State to another. . .."118 Similar terminology governs states' obligations to the ad hoc tribunals. ${ }^{119}$

The United States typically hands over fugitives - including its own nationals - only in accordance with extradition treaties. ${ }^{120}$ In the case of the ICTR, the United States did not negotiate a treaty; rather, a U.S. statute implemented an agreement between the President and the ad hoc tribunal. ${ }^{121}$ A U.S. magistrate refused to surren-

113. ICC Statute, supra n. 1, art. 77.

114. Id., art. 106(2).

115. Id.

116. Wedgwood, "The Constitution and the ICC," in The United States and the International Criminal Court 119, 128 (Sarah B. Sewall \& Carl Keysen eds., 2000) [hereinafter Wedgwood, Constitution].

117. ICC Statute, supra n. 1, arts. 58, 59; See generally id., arts. 86-102.

118. Id., art. 102.

119. ICTY Statute, supra n.10, art. 29(2)(e) ("States shall comply without undue delay with any request for assistance or an order issued by a Trial Chamber, including, but not limited to ... the surrender or the transfer of the accused to the International Tribunal"); ICTR Statute, supra n. 10, art. 28(2)(e) (same).

120. See 18 U.S.C. $\$ \$ 3183,3196$ (2000) (providing for extradition of U.S. citizens and nationals); Amann, Whipsaw, supra n. 71, at 1265-66 (stating that the United States has in force more than a hundred bilateral and multilateral treaties).

121. See National Defense Authorization Act, Pub. L. 104-106, $\S 1342,110$ Stat. 486 (1996) (implementing Agreement on Surrender of Persons Between the Government of the United States and the International Tribunal for the Prosecution of Persons Responsible for Genocide and Other Serious Violations of International Humanitarian Law Committed in the Territory of Rwanda and Rwandan Citizens Responsible for Genocide and Other Such Violations Committed in the Territory of Neighboring States, Jan. 24, 1995, U.S.-Int'l Trib. Rwanda, available at 1996 WL 165484) [hereinafter Defense Act]. 
der a fugitive, on the ground that the Constitution required an extradition treaty. ${ }^{122}$ This decision did not stand, however; a divided panel of the U.S. Court of Appeals for the Fifth Circuit held that the Constitution also permits the transfer of fugitives pursuant to laws enacted by Congress. ${ }^{123}$ Assuming that the latter opinion is correct, "surrender" within the meaning of the ICC Statute ought not to pose constitutional difficulties, at least if, as with the ICTR case, surrender adhered to procedural protections typical in extradition proceedings. ${ }^{124}$ These include two guaranteed by the Constitution: a judicial hearing to assure that the transfer request is supported by sufficient evidence, and the right to petition for a writ of habeas corpus. ${ }^{125}$

Another common constraint on fugitive transfers is lapse of time. In keeping with the convention holding certain international offenses imprescriptible, ${ }^{126}$ the ICC Statute mandates that crimes within its jurisdiction "shall not be subject to any statute of limitations." 127 That is not the case in the United States. Its Genocide Convention Implementation Act of 1987 does state that there is no limitations period for genocidal killing. ${ }^{128}$ But by implication, domestic prosecution of other genocidal acts, such as the infliction of serious physical or mental harm, would have to take place within the general limitations period of five years. ${ }^{129}$ The same would seem to be true for war crimes and for torture not punishable by death, ${ }^{130}$ although in all cases the limitations period could be tolled if the indictment alleged a conspiracy or other continuing offense. ${ }^{131}$ In any event, these discrepancies alone ought not to prevent surrender, because the limitations defense to extradition appears to derive from treaties and not from the Constitution. Indeed, U.S. law provides that if an extradi-

122. In re Surrender of Ntakirutimana, 988 F. Supp. 1038, 1042 (S.D. Tex.1997).

123. Ntakirutimana v. Reno, 184 F.3d 419, 424-25 (5th Cir. 1999) (citing Valentine v. United States, 299 U.S. 5, 8-9 (1936)). Despite a spirited dissent, id. at 431-36 (DeMoss, J.), the U.S. Supreme Court declined to review the decision, 528 U.S. 1135 (2000) (denying certiorari).

124. See Defense Act, supra n.121, $\$ 1342(a)$ (1) (conditioning surrender to ICTR on adherence to procedures in U.S. extradition statutes, 18 U.S.C. $\$ \S 3181-3196)$ ).

125. See U.S. Const., art. I, \& 9 (habeas corpus); id., amend. IV (requiring that warrants issue only on probable cause); Fernandez v. Phillips, 268 U.S. 311, 312 (1925) (detailing limits on habeas corpus review); Ntakirutimana v. Reno, 184 F.3d at 427 (stating that determination fulfills constitutional probable cause requirement).

126. Convention on the Non-Applicability of Statutory Limitations to War Crimes and Crimes against Humanity, Nov. 26, 1968, 754 U.N.T.S. 73; See U.N. Treaty Collection [as of 11 June 2001], http://www.unhchr.ch/html/menu3/b/treaty6.htm (visited Sept. 20, 2001) (indicating that United States is not a party to this convention).

127. ICC Statute, supra note 1, art. 29.

128. 18 U.S.C. $\$ 1091(\mathrm{e})(2000)$.

129. See 18 U.S.C. $\S 3282(2000)$.

130. See 18 U.S.C. $\$ 2441$ (2000) (omitting mention of limitations issue with regard to war crimes); 18 U.S.C. $\$ \S 2340-2340$ B (2000) (same respecting torture): U.S. law forbids any limitations period for capital offenses. 18 U.S.C. $\$ 3281(2000)$.

131. See, e.g., United States v. Yashar, 166 F.3d 873 (7th Cir. 1999). 
tion treaty places no time limits on prosecution abroad, no time-bar applies. ${ }^{132}$

Yet another protection, the principle of double criminality, could present difficulty. This requires that the offense at issue be punishable both in the requesting state and in the asylum state. Both the ICC Statute and the U.S. criminal code proscribe genocide, war crimes, and torture. ${ }^{133}$ Double criminality would seem to be met with regard to these crimes, even though the descriptions of offenses and potential punishments differ. ${ }^{134}$ This would not be the case for other crimes against humanity, for U.S. law says nothing of them. ${ }^{135}$ Clearly there is no double criminality. The effect of this is unclear, however. On the one hand, the protection derives not from the Constitution but from the content of treaties and the practice of states. ${ }^{136}$ On the other hand, a court could find in the protection a purpose of constitutional stature, an insurance against deprivation of liberty without due process of law. ${ }^{137}$ Due process requires, for example, that individuals have fair warning that their conduct could subject them to criminal prosecution. Exercise of U.S. authority to surrender a person to stand charges for conduct that U.S. laws do not define as criminal might be seen to infringe on this principle. ${ }^{138}$

\section{G. U.S. Constitutional Framework and the ICC Statute}

Analysis reveals that the ICC Statute is compatible with many specific U.S. constitutional protections. ${ }^{139}$ Yet attributes of the ICC Statute remain under attack. The power to investigate matters without the approval of the Security Council - and so of the United States, a permanent Council member - is viewed as menace to U.S. sovereignty and the democratic principle of government. Though not stated explicitly in the U.S. Constitution, the concept of sovereignty surely has a constitutional, or constitutive, dimension. In the words of John Marshall, the influential early Chief Justice of the United

132. See Restatement (Third) of the Foreign Relations Law of the United States $\S 476 \mathrm{cmt}$. e (1986) [hereinafter Restatement] ("If the treaty contains no reference to the effect of a lapse of time, neither state's statute of limitations will be applied.").

133. Compare ICC Statute, supra n. 1, arts. 6 (genocide), 7(f) (torture as crime against humanity), 8 (war crimes) with 18 U.S.C. $\$ \S 1091-93$ (2000) (genocide), id. $\S \S 2340-2340 \mathrm{~B}$ (torture), id. $\S \S 2441$ (war crimes).

134. See Collins v. Loisel, 259 U.S. 309, 312 (1922) (stating that crimes need not be "coextensive," and that double criminality is met as long as acts are criminal in both jurisdictions).

135. See Cassel, "Empowering United States Courts to Hear Crimes Within the Jurisdiction of the International Criminal Court," 35 New Eng. L. Rev. 421, 429 \& n.39 (2001) (listing certain acts of international terrorism, proscribed in U.S. law, that also may constitute crimes against humanity).

136. See Restatement, supra n. $132, \S 476 \mathrm{cmt}$. d.

137. See U.S. Const., amend. V.

138. See Jordan v. De George, 341 U.S. 223, 230 (1951).

139. Accord Benison, supra n. 70, at 76-77, 115 (concluding the Constitution's provision regarding treaties presents no bar to U.S. participation). 
States, "The jurisdiction of the nation, within its own territory, is necessarily exclusive and absolute ...."140 At the beginning of the twentieth century, the United States relied on this principle to object to proposed international prosecution of a foreign head of state, ${ }^{141}$ though it must be noted that by century's end, it endorsed the international indictment of a foreign head of state. ${ }^{142}$ It seems certain that the United States would invoke this principle of territorial sovereignty as grounds for refusing to surrender an incumbent President, its own head of state, to the ICC. Even assuming the principle still governs U.S. law, however, it alone does not preclude U.S. cooperation with the ICC. Marshall's opinion made clear that a state may consent to limitations on its sovereignty. ${ }^{143}$ This power to consent ought to extend to the United States vis-à-vis the ICC. ${ }^{144}$ U.S. opponents of the ICC strenuously object to consideration of such consent; for them, the question comes down to whether the Assembly of States Parties would, as currently constituted, violate the fundamental democratic and republican principles of the Constitution. ${ }^{145}$

Some aspects of the ICC Statute give justifiable pause to lawyers trained in U.S. constitutional law. These include the absence of a search-and-seizure clause, the specter of surrender for offenses not named in the U.S. code, and conditions of imprisonment abroad. The Constitution would forbid a U.S. court to follow certain ICC practices - no chance for trial by jury, possible use of anonymous witnesses, and consideration of a prosecutor's appeal following acquittal. The

140. Schooner Exchange v. McFaddon, 11 U.S. (7 Cranch) 116, 136 (1812). See also Coleman v. Tennessee, 97 U.S. 509, 515-16 (1878) (applying Schooner Exchange holding to case arising out of U.S. civil war, and writing that invading Union soldiers were not subject to tribunals in enemy territory, but "were answerable only to their own government, and only by its law, as enforced by its armies, could they be punished").

141. See "Memorandum of Reservations Presented by the Representatives of the United States to the Report of the Commission on Responsibilities" (Annex II to the Report of the Commission on the Responsibility of the Authors of the War and the Enforcement of Penalties) (criticizing proposal to try Kaiser Wilhelm II), reprinted in 14 Am. J. Int'l L. 127, 147-50 (1920).

142. See Roger Cohen, "Warrants Served for Serbs' Leader and 4 Assistants," N.Y. Times, May 28, 1999, at A1 (reporting on U.S. approval of ICTY indictment of Yugoslav President Slobodan Milošević).

143. Schooner Exchange, 11 U.S. (7 Cranch) at 136; See Wilson, 354 U.S. at 529 ("A sovereign nation has exclusive jurisdiction to punish offenses against its laws committed within its borders, unless it expressly or impliedly consents to surrender its jurisdiction.") (emphasis added).

144. Accord Louis Henkin, Foreign Affairs and the United States Constitution 26869 (2d ed. 1996) ("[T]here is nothing in the Constitution that would seem to forbid the United States to agree to an international tribunal, whether sitting in the United States or elsewhere, that would apply international law to acts committed by individual in the United States, including U.S. citizens and residents.").

145. For standard summaries of the democratic and republican principles of the U.S. Constitution, see the three-volume treatise John Adams, A Defence of the Constitutions of Government of the United States of America (1787-88), and also the essays by "Publius" (Alexander Hamilton, John Jay, and James Madison) in The Federalist (1787-88). 
United States could resolve one conflict, the dearth of double criminality, by implementing proper domestic legislation at the time of ratification. ${ }^{146}$ Reconciling other differences will prove more difficult, given the ICC ban on reservations. ${ }^{147}$ Some states have amended their constitutions in order to ratify the ICC treaty, but there is no chance that such an amendment would be approved in the United States. ${ }^{148}$ If identity of U.S. law and ICC law were necessary, therefore, certain substantive and procedural differences could frustrate U.S. ratification.

Some ICC supporters do urge states to enact provisions identical to those in the ICC Statute. An Amnesty International pamphlet, for example, calls for domestic laws with the same crimes, the same universal jurisdiction, the same concepts of penal responsibility, the same limits on defenses, and the same punishments. ${ }^{149}$ Even U.S. skeptics may favor such legislation. That is because of the principle of complementarity, which precludes ICC intervention in cases that a state has handled in its domestic system, adequately and in good faith. ${ }^{150}$ The more U.S. laws conform to those of the ICC, the more the U.S. legal system can deal with cases that might interest the ICC, and thus shield U.S. nationals from international prosecution. ${ }^{151}$

146. This would follow precedents set in the 1990s, when the Senate conditioned ratification of the Genocide Convention, supra n. 75, and the Convention Against Torture and Other Cruel, Inhuman, Degrading Treatment or Punishment, G.A. Res. 39/ 46, U.N. GAOR, Annex, Supp. No. 51, at 197, U.N. Doc. A/39/51 (1984), on enactment of implementing legislation. See Bradley \& Goldsmith, "Treaties, Human Rights, and Conditional Consent," 149 U. Pa. L. Rev. 399, 420 n.100, 427-28 \& n.129 (2000). Such implementation could spawn problems regarding U.S. cooperation, however, in the event that the ICC ever sought surrender of an individual whom the President had pardoned for an offense that, as a result of implementation, appeared in the U.S. criminal code. See supra $\S$ III(C).

147. ICC Statute, supra n. 1, art. 120, discussed supra § II(D). This report does not explore the possibility that the United States might secure assurances, understandings, or interpretive statements conditioning U.S. participation. At least one commentator advocated this vehicle, which the United States pursued unsuccessfully in preparatory sessions. See Wedgwood, Constitution, supra n. 116, at 119-20, 128-30. Others, however, maintained that it would violate the ICC treaty. See Gennady M. Danilenko, "The Statute of the International Criminal Court and Third States," 21 Mich. J. Int'l L. 393, 492-93 (2000); Gerhard Hafner et al., "A Response to the American View as Presented by Ruth Wedgwood," 10 Eur. J. Int'l L. 108, 119 (1999).

148. See Duffy, supra n. 77, at 9-13 (discussing amendment approach of France, Brazil, Belgium and Germany); "World Court Laws Adopted," Afr. News (Mar. 29, 2001), available at LEXIS, News Library, News Group File (reporting that eight African states had amended their constitutions to comport with the ICC treaty). The mechanism for amendment, U.S. CoNST., art. V, has been effectuated only twentyseven times in two centuries, and never to conform the Constitution to a treaty obligation.

149. Amnesty International, "Cour pénale internationale," Index AI: IOR 40/011/ 00-ÉFAI (2000), at 6-11 (on file with author).

150. See ICC Statute, supra n. 1, arts. 1, 17(1)(a)-(c), 18, 19(2)(b), 20(3).

151. See Cassel, supra n. 135, at 436-47; Wedgwood, Constitution, supra n. 116, at 127. 
Although identity of laws may be politically desirable, as a matter of U.S. constitutional law, it may not be necessary. Opponents have argued to the contrary, essentially equating U.S. judicial power with judicial power exercised by a foreign body with U.S. consent. ${ }^{152}$ But that view is at odds with numerous U.S. opinions permitting variance. ${ }^{153}$ U.S. military tribunals are permitted to follow procedures that differ from those in civilian courts. ${ }^{154}$ Furthermore, the United States has a history of cooperating with courts abroad in spite of differences. These include not only the post-World War II international military tribunals and today's ad hoc international criminal tribunals, but also courts in the myriad states with which the United States has extradition and other judicial-assistance agreements. ${ }^{155}$ The Constitution has been held to allow transfer of a fugitive to the ICTR. ${ }^{156}$ The Supreme Court long ago established that unless a treaty requires otherwise, courts may not refuse surrender for the sole reason that the fugitive is a U.S. national. ${ }^{157}$ U.S. courts also have rejected U.S. nationals' claims that the Constitution forbids their surrender to foreign courts that follow procedures unlike those in the United States. ${ }^{158}$ Indeed, applying the rule of non-inquiry, U.S. courts ordinarily refuse even to look at the criminal justice system of a state requesting extradition. ${ }^{159}$ U.S. cooperation is of course a form of state action, and thus must accord with the Due Process Clause. But courts considering challenges to cooperation seldom, if ever, find a violation of this guarantee. ${ }^{160}$

152. See Casey \& Rivkin statement, supra n. 45 .

153. See Henkin, supra n.144, at 268-70 (summarizing and refuting such equationof-power arguments).

154. See supra $\S \operatorname{III}(D)$.

155. See Amann, Whipsaw, supra n. 71, at 1263-67. U.S. cooperation extends further to commercial panels established pursuant to pacts like the North American Free Trade Agreement. See Wedgwood, Constitution, supra n. 116, at 121-22.

156. Ntakirutimana v. Reno, 184 F.3d at 421.

157. Charlton v. Kelly, 229 U.S. 447, 467-68 (1913).

158. E.g., Wilson v. Girard, 354 U.S. 524, 525-30 (1957) (finding that the Constitution does not prevent U.S. courts from cooperating with Japanese court that had convicted U.S. soldier of homicide); Neely v. Henkel, 180 U.S. 109, 112-14, 122-23 (1901) (permitting extradition of U.S. citizen for trial in Cuba on charges of embezzlement and fraud, despite claim that foreign system lacked constitutional protection like habeas corpus, prohibition on ex post facto laws, and right to jury trial); Holmes v. Laird, 459 F.2d 1211, 1212, 1217-20 (D.C. Cir.) (sustaining German court's convictions of U.S. soldiers for attempted rape, notwithstanding procedural differences), cert. denied, 409 U.S. 869 (1972).

159. See Semmelman, "Federal Courts, the Constitution, and the Rule of Non-Inquiry in International Extradition Proceedings," 76 Cornell L. Rev. 1198, 1198 (1991).

160. See, e.g., United States v. Balsys, 524 U.S. 666, 698 (1998) (Stevens, J., concurring) (stating that due process not violated by compelling U.S. witness to give testimony that might be used against him in foreign prosecution, on ground that foreign use of such testimony "will not have any adverse impact on the fairness of American criminal trials"); Cornejo-Barreto v. Seifert, 218 F.3d 1004, 1010 (9th Cir. 2000) (accepting possibility that, as was proposed in Gallina v. Fraser, 278 F.2d 77, 79 (2d Cir.), cert. denied, 364 U.S. 851 (1960), court may be barred from surrendering fugitive to state with offensive procedures or punishment, but declining to apply, and 
None of these situations, it is true, perfectly matches the ICC. The ICC is sui generis, neither a military court nor the court of a sovereign state. Unlike prior international criminal tribunals, the ICC, and the obligations that it imposes on states parties, is permanent. Nevertheless, these models of cooperation suggest that, as long as the ICC's practices meet minimum standards of fairness, they should not prevent U.S. participation in the international court.

\section{Prospects for U.S. Ratification}

Most of the discrepancies between the U.S. Constitution and the ICC Statute may be reconcilable. Nevertheless, differences between the ICC's structure and U.S. traditions will continue to provoke vehement protests. ICC opponents, many of whom hold key positions in the Bush Administration or in Congress, have underscored their mistrust of an international court that grants equal voting status to every member state, including those that are not democratic. The U.S. delegates did seek innovations that might ease critics' concerns; thus they worked to regain oversight power for the Security Council, to exempt U.S. nationals from the ICC's jurisdiction, and to create means for conditional consent to the ICC treaty. The refusal of ICC signatories to agree to these restrictions confirmed many U.S. opponents' hostility to the court. The U.S. government might be willing to join an International Criminal Court with jurisdiction limited to cases that the Security Council - which is, of course, subject to the U.S. veto - referred to it. That arrangement, however, is no longer possible. Therefore, the United States is very unlikely either to join or to support the International Criminal Court at any time in the foreseeable future.

noting that "[o]ur research failed to identify any case in which this theoretical exception has been applied"). Cf. Neely, 180 U.S. at 123 (permitting extradition of U.S. citizen to Cuba based on U.S. law that guaranteed him "'a fair and impartial trial" not necessarily a trial according to the mode prescribed by this country for crimes committed against its laws, but a trial according to the modes established in the country where the crime was committed, provided such trial be had without discrimination against the accused because of his American citizenship"). 